\title{
Arahan Optimalisasi RTH Publik Kecamatan Kelapa Gading, Jakarta Utara
}

\author{
Shella Anastasia dan Haryo Sulistyarso \\ Jurusan Perencanaan Wilayah dan Kota, Fakultas Teknik Sipil dan Perencanaan \\ Institut Teknologi Sepuluh Nopember (ITS) \\ Jl. Arief Rahman Hakim, Surabaya 60111 Indonesia \\ e-mail: haryo.its@gmail.com
}

\begin{abstract}
Abstrak - Ruang Terbuka Hijau merupakan salah satu elemen penting yang harus dimiliki setiap wilayah. Keberadaannya mampu meningkatkan nilai ekologis, ekonomi, sosial, dan estetis. Kecamatan Kelapa Gading merupakan kecamatan di Jakarta Utara yang memiliki permasalahan terkait kualitas RTH publik. Sehingga dibutuhkan optimalisasi RTH publik yang ada agar dapat meningkatkan nilai ekologis, ekonomi, sosial dan estetis Kecamatan Kelapa Gading. Dengan metode deskriptif kualitatif, penelitian ini menghasilkan arahan optimalisasi RTH berdasarkan kondisi eksisting, kebutuhan, dan faktor yang mempengaruhi optimalisasi RTH. Hasil analisis menunjukkan bahwa RTH yang terdapat di Kecamatan Kelapa Gading meliputi taman dan jalur hijau, sedangkan RTH yang dibutuhkan ialah RTH dengan fungsi ekologis, sosial, estetis, dan ekonomi. Dari analisis Delphi diketahui bahwa faktor yang mempengaruhi optimlisasi RTH publik adalah penyelenggaraan program RTH, pengawasan dan pengelolaan pemerintah, koordinasi dan kerjasama pihak swasta, adanya lahan kosong yang berfungsi sebagai RTH, pemanfaatan lahan, jumlah penduduk, tingkat pertumbuhan penduduk, karakteristik penduduk, wawasan masyarakat, kepedulian masyarakat dan tingkat partisipasi masyarakat. Sedangkan arahan optimalisasi dalam penelitian ini meliputi peningkatan kualitas RTH dengan fungsi ekologis, ekonomi, sosial, estetis, dan fungsi campuran.
\end{abstract}

Kata Kunci-Optimalisasi RTH, RTH publik

\section{PENDAHULUAN}

$\mathrm{R}$ uang terbuka hijau merupakan suatu area memanjang atau mengelompok yang penggunaannya lebih bersifat terbuka, tempat tumbuh tanaman, baik yang tumbuh secara alamiah maupun yang sengaja ditanam [1]. Sedangkan ruang terbuka hijau publik merupakan ruang terbuka hijau yang berlokasi pada lahan publik atau lahan milik pemerintah [2].

Ibukota DKI Jakarta memiliki beberapa permasalahan terkait RTH meliputi penyediaan, penyebaran, serta kualitas RTH publik dan privat di seluruh wilayah [3]. Luasan RTH DKI Jakarta saat ini hanya seluas $6.874,06$ ha atau hanya sebesar 9,8\% dari luas total DKI Jakarta, yaitu $66.233,00$ ha [4]. Target RTH Publik DKI Jakarta sebesar $20 \%$ atau seluas 12.891,41 ha didistribusikan ke dalam 5 wilayah DKI yaitu Jakarta Pusat (623,08 ha), Jakarta Barat (1.946,61 ha), Jakarta Selatan $(2.947,83$ ha), Jakarta Timur $(4.340,11$ ha), dan Jakarta Utara (3.033,78 ha) [5]. Faktanya, luasan RTH publik saat ini yaitu Jakarta Pusat (589,16 ha), Jakarta Barat (515,71 ha), Jakarta Selatan (621,25 ha), Jakarta Timur (589,16 ha), dan Jakarta Utara (452,81 ha) [6].

Kecamatan Kelapa Gading merupakan salah satu kecamatan yang terdapat di wilayah Jakarta Utara dengan luas wilayah 161,21 ha yang terbagi menjadi 3 kelurahan dengan total penduduk sebanyak 156.664 jiwa [7]. Kondisi eksisting RTH di Kecamatan Kelapa Gading saat ini yaitu sebesar 18,15 ha atau sebesar $11,25 \%$ dari total luas wilayah yang dimiliki [8]. Data tersebut menunjukkan bahwa keberadaan RTH di Kecamatan Kelapa Gading mencakup 0,93 $\mathrm{m}^{2} /$ jiwa dan sudah memenuhi standar yang ada [9]. Namun, adanya pemanfaatan RTH yang belum optimal dapat menyebabkan adanya kemungkinan perubahan penggunaan lahan dari RTH menjadi kawasan terbangun.

Selain itu, terdapat permasalahan terkait RTH di Kecamatan Kelapa Gading dalam aspek ekologis, sosial, ekonomi dan estetis. Dalam aspek ekologis, diketahui bahwa Kecamatan Kelapa Gading memiliki 7 titik lokasi yang menjadi wilayah banjir setiap tahunnya dan memiliki 42 titik rawan banjir [10]. Kecamatan Kelapa Gading juga merupakan salah satu kecamatan yang memiliki beberapa pusat perbelanjaan yang luasnya melebihi RTH yang ada yaitu seluas $996.215 \mathrm{~m}^{2}$ [11]. Padahal, dalam aspek sosial, Jakarta sebagai kota yang dihuni oleh jutaan warga dengan beragam problematika kota ini seharusnya memiliki RTH yang cukup [12]. Begitu pun dengan Kecamatan Kelapa Gading, sebagai kecamatan yang dihuni oleh 156.664 jiwa, seharusnya memiliki RTH publik yang dapat dimanfaatkan masyarakat untuk berinteraksi, berekspresi, berekreasi dan melepas kepenatan kota Jakarta.

Dalam aspek ekonomi, terdapat beberapa RTH di Kecamatan Kelapa Gading yang telah ditanami tanaman obat namun belum dimanfaatkan secara optimal dalam bidang ekonomi [13]. Sedangkan dalam aspek estetis, terdapat beberapa RTH publik berupa taman yang kondisinya kurang baik dan belum optimal secara estetis. Salah satunya ialah Taman Interaksi di Jalan Perintis Kemerdekaan, Kelapa Gading Timur yang hanya berupa tanah merah dan hanya memiliki sedikit pohon [14]. Hal tersebut menunjukkan masih adanya masalah RTH dalam segi estetis.

Dengan terdapatnya beberapa masalah terkait RTH dalam aspek ekologis, sosial, ekonomi dan estetis maka dibutuhkan optimalisasi RTH publik di Kecamatan Kelapa Gading agar dapat menjadi solusi dari permasalahan RTH yang ada. 


\section{METODE PENELITIAN}

\section{A. Jenis dan Pendekatan Penelitian}

Pendekatan yang digunakan dalam penelitian ini adalah pendekatan rasionalistik. Jenis penelitian dalam penelitian ini adalah deskripsi kualitatif.

\section{B. Variabel Penelitian}

Variabel yang digunakan dalam penelitian ini adalah : jenis RTH publik, fungsi RTH publik, skala RTH, fisik binaan, fisik alami, luas RTH publik, jenis dan fungsi tanaman, program penyediaan dan pengelolaan RTH, pengawasan dan pengendalian, kerjasama dengan pihak swasta, keterbatasan jumlah lahan, adanya alih fungsi lahan, kejelasan status kepemilikan lahan, jumlah penduduk suatu kawasan, dan tingkat pertumbuhan penduduk.

\section{Mengidentifikasi Karakteristik RTH Publik di Kecamatan} Kelapa Gading

Karakteristik RTH Publik di Kecamatan Kelapa Gading, diperoleh melalui analisis kualitatif dengan metode analisis deskriptif model Miles and Huberman. Pandangan Miles dan Huberman terhadap penelitian kualitatif adalah penelitian yang memiliki data berupa kata-kata dan bukan rangkaian angka. Data dalam penelitian dapat dikumpulkan melalui observasi, wawancara, intisari dokumen, serta dokumen rekaman. Namun analisis kualitatif tetap menggunakan katakata, yang biasanya disusun dalam teks yang diperluas. Secara umum, aktivitas dalam analisis ini meliputi reduksi data, penyajian data, serta penarikan kesimpulan dan verifikasi data.

\section{Mengidentifikasi Kebutuhan RTH Publik di Kecamatan} Kelapa Gading

Untuk mengidentifikasi kebutuhan RTH Publik Kecamatan Kelapa Gading berdasarkan preferensi masyarakat, digunakan teknik analisis statistik deskriptif. Menurut Sugiyono (2004) statistik deskriptif ialah statistik yang digunakan untuk menganalisa data dengan cara mendeskripsikan atau menggambarkan data yang telah terkumpul sebagaimana adanya tanpa bermaksud membuat kesimpulan yang berlaku untuk umum atau generalisasi. Metode ini dilakukan dengan membentuk design kuisioner yang akan disebarkan kepada masyarakat pengguna RTH di Kecamatan Kelapa Gading untuk mendapatkan preferensi terkait fungsi RTH yang dibutuhkan.

E. Menganalisis Faktor Pengaruh Optimalisasi RTH Publik di Kecamatan Kelapa Gading

Faktor pengaruh optimalisasi RTH di Kecamatan Kelapa
Gading diketahui dengan melakukan analisis kualitatif menggunakan metode Delphi. Metode analisis kualitatif dinilai lebih tepat terkait jenis data yang digunakan dalam mengidentifikasi faktor apa yang sebenarnya berpengaruh dalam upaya optimalisasi RTH di Kelapa Gading. Selain itu, analisis kualitatif sesuai untuk menggali persepsi, asumsi, penilaian dan prasangka manusia. Metode ini meliputi beberapa tahap yaitu spesifikasi permasalahan dan merumuskan kuisioner I, wawancara Delphi putaran I, analisis hasil putaran I, serta penyusunan kuisioner selanjutnya (iterasi).

\section{F. Merumuskan Arahan Optimalisasi RTH Publik di Kecamatan Kelapa Gading}

Untuk menentukan arahan optimalisasi RTH yang sesuai untuk dikembangkan di Kecamatan Kelapa Gading akan dilakukan dengan menggunakan analisis Theoritical Descriptive dengan teknik validasi triangulasi. Teknik triangulasi pada dasarnya menggunakan 3 sumber data yang nantinya akan dijadikan sebagai pertimbangan dalam penentuan arahan optimalisasi RTH publik di Kecamatan Kelapa Gading yang implementatif. Dalam penelitian ini, sumber informasi yang akan digunakan adalah kebijakan yang berhubungan dengan penelitian, pustaka lain, diluar pustaka yang dijadikan sebagai acuan penelitian, yang berhubungan dengan penelitian. Pustaka dapat berupa teori para ahli atau pun hasil penelitian lain yang menyerupai penelitian ini, dan hasil penelitian.

\section{HASIL DAN PEMBAHASAN}

\section{A. Karakteristik RTH Publik Kecamatan Kelapa Gading}

Karakteristik RTH di Kecamatan Kelapa Gading terdiri dari beberapa aspek yaitu jenis dan fungsi RTH, kondisi fisik RTH, skala RTH, serta vegetasi yang terdapat dalam RTH Kecamatan Kelapa Gading.

Jenis RTH Publik yang terdapat di Kecamatan Kelapa Gading yaitu berupa taman kota dengan skala lingkup kota, taman lingkungan yang berada di kawasan permukiman masyarakat dengan skala RW, serta jalur hijau di beberapa jalan yang ada meliputi jalur hijau median jalan dan jalur hijau tepi jalan. Seluruh RTH publik di Kecamatan Kelapa Gading merupakan RTH dengan fisik binaan yaitu RTH yang memang disediakan secara buatan. Terdapat beberapa fungsi yang dimiliki oleh RTH publik di Kecamatan Kelapa Gading yaitu fungsi ekologis sebagai peneduh, fungsi sosial sebagai tempat rekreasi dan fungsi estetis sebagai pembentuk faktor keindahan

arsitektural 


\section{B. Kebutuhan RTH Publik Kecamatan Kelapa Gading}

Analisis kebutuhan RTH Publik di Kecamatan Kelapa Gading dilakukan dengan melalui 2 tahap yaitu menghitung luasan RTH publik yang dibutuhkan dan mengidentifikasi kebutuhan RTH publik menurut fungsinya berdasarkan preferensi masyarakat.

1) Kebutuhan RTH ditinjau dari Jumlah Penduduk Menurut Permen PU No. 5 Tahun 2008

Berdasarkan Permen PU No.5 Tahun 2008, kebutuhan penyediaan RTH dapat ditinjau berdasarkan jumlah penduduk suatu kawasan. Taman kecamatan yang disediakan untuk unit lingkungan dengan jumlah penduduk 120.000 jiwa minimal harus mencakup 0,2 $\mathrm{m}^{2} /$ jiwa. Sehingga berdasarkan standar tersebut, maka untuk Kecamatan Kelapa Gading dengan jumlah penduduk sebanyak 156.664 jiwa, lahan yang dibutuhkan untuk RTH adalah $\mathbf{3 1 . 3 3 2} \mathbf{~ m}^{2}$.

2) Kebutuhan RTH Ditinjau dari Fungsi Berdasarkan Preferensi Masyarakat

Analisis ini dilakukan melalui hasil kuisioner yang telah diisi oleh 35 masyarakat Kecamatan Kelapa Gading. Kuisioner diisi oleh masyarakat untuk mengetahui fungsi RTH yang dibutuhkan di wilayah penelitian. Dalam analisis ini, dihasilkan 3 fungsi terpenting dan yang paling dibutuhkan dari masing-masing fungsi RTH (ekologis, sosial, estetis, ekonomi) yang dapat menjadi prioritas dalam optimalisasi RTH publik yang ada.

Hasil kuisioner untuk RTH dengan fungsi ekologis ialah RTH atau taman yang berfungsi sebagai resapan air, berfungsi sebagai paru-paru kota, dan berfungsi sebagai peneduh.

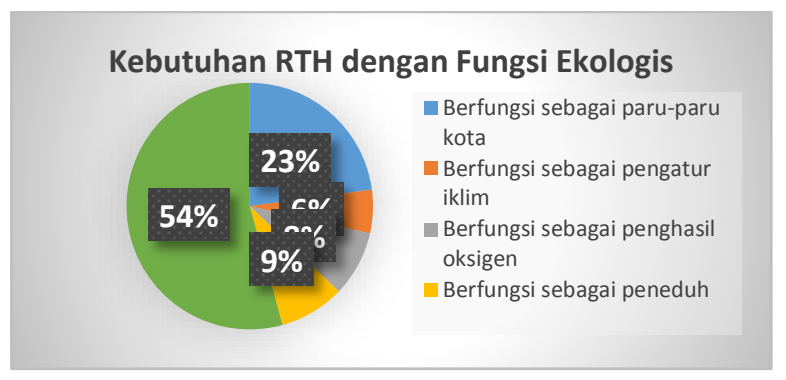

Gambar 1. Kebutuhan RTH dengan Fungsi Ekologis

Sedangkan untuk RTH dengan fungsi sosial ialah RTH yang berfungsi sebagai tempat rekreasi, media komunikasi warga, dan menggambarkan ekspresi budaya lokal.

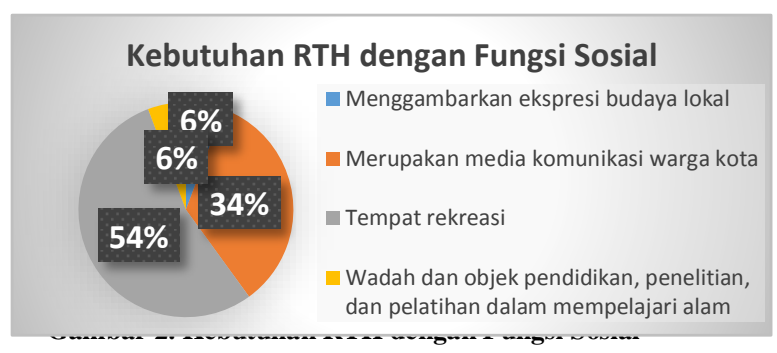

Hasil kuisioner untuk RTH dengan fungsi ekonomi ialah RTH dengan sumber produk yang bisa dijual, sedangkan untuk RTH dengan fungsi estetis dibutuhkan RTH yang dapat meningkatkan kenyamanan, berfungsi sebagai pembentuk faktor keindahan arsitektural, serta RTH yang dapat menstimulasi kreativitas dan produktivitas warga kota.

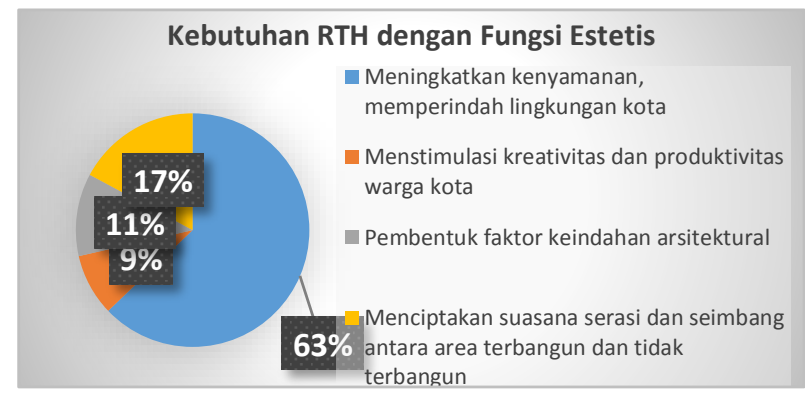

Gambar 1. Kebutuhan RTH dengan Fungsi Estetis

\section{Faktor Pengaruh Optimalisasi RTH Publik di Kecamatan Kelapa Gading}

Analisis Delphi pada tahap ini dilakukan dengan melalui satu kali iterasi. Hasil Analisis tahap I adalah sebagai berikut:

Tabel 1.

Hasil Analisis Delphi Tahap I

\begin{tabular}{|c|c|c|c|c|c|c|c|c|c|c|}
\hline \multirow[t]{2}{*}{ Faktor } & \multirow[t]{2}{*}{ Variabel } & \multicolumn{9}{|c|}{ Pendapat Responden } \\
\hline & & R1 & $\mathbf{R 2}$ & $\mathbf{R 3}$ & $\mathbf{R 4}$ & R5 & R6 & R7 & $\mathbf{R 8}$ & $\mathbf{R 9}$ \\
\hline \multirow[t]{3}{*}{$\begin{array}{l}\text { Faktor } \\
\text { Kelembagaan }\end{array}$} & $\begin{array}{l}\text { Penyelenggaraan program- } \\
\text { program terkait RTH }\end{array}$ & $\mathrm{S}$ & $\mathrm{S}$ & $\mathrm{S}$ & $\mathrm{S}$ & $\mathrm{S}$ & $\mathrm{S}$ & $\mathrm{S}$ & $\mathrm{S}$ & $\mathrm{S}$ \\
\hline & $\begin{array}{l}\text { Upaya pemerintah dalam } \\
\text { pengawasan dan pengelolaan } \\
\text { RTH }\end{array}$ & $\mathrm{S}$ & $\mathrm{S}$ & $\mathrm{S}$ & $\mathrm{S}$ & $\mathrm{S}$ & $\mathrm{S}$ & $\mathrm{S}$ & $S$ & $\mathrm{~S}$ \\
\hline & $\begin{array}{l}\text { Koordinasi dan kerjasama dengan } \\
\text { pihak swasta }\end{array}$ & $\mathrm{S}$ & $\mathrm{S}$ & $\mathrm{S}$ & $\mathrm{S}$ & $\mathrm{S}$ & $\mathrm{S}$ & $\mathrm{S}$ & $\mathrm{S}$ & $\mathrm{S}$ \\
\hline \multirow[t]{3}{*}{$\begin{array}{l}\text { Faktor Tata } \\
\text { Guna Lahan }\end{array}$} & $\begin{array}{l}\text { Jumlah lahan kosong yang } \\
\text { difungsikan menjadi RTH }\end{array}$ & $\mathrm{S}$ & $\mathrm{S}$ & $\mathrm{S}$ & TS & $\mathrm{S}$ & TS & TS & $\mathrm{S}$ & $\mathrm{S}$ \\
\hline & Pemanfaatan lahan & $\mathrm{S}$ & $\mathrm{S}$ & $\mathrm{S}$ & $\mathrm{S}$ & $\mathrm{S}$ & $\mathrm{S}$ & $\mathrm{S}$ & $\mathrm{S}$ & $\mathrm{S}$ \\
\hline & Status kepemilikan lahan & $\mathrm{S}$ & TS & $\mathrm{S}$ & $\mathrm{S}$ & TS & TS & $\mathrm{S}$ & TS & TS \\
\hline \multirow{2}{*}{$\begin{array}{l}\text { Faktor } \\
\text { Demografi }\end{array}$} & Jumlah penduduk & $\mathrm{S}$ & $\mathrm{S}$ & $\mathrm{S}$ & TS & $\mathrm{S}$ & $\mathrm{S}$ & $\mathrm{S}$ & $\mathrm{S}$ & $\mathrm{S}$ \\
\hline & Tingkat pertumbuhan penduduk & $\mathrm{S}$ & $\mathrm{S}$ & $\mathrm{S}$ & $\mathrm{S}$ & $\mathrm{S}$ & $\mathrm{S}$ & $\mathrm{S}$ & $\mathrm{S}$ & $\mathrm{S}$ \\
\hline
\end{tabular}




\begin{tabular}{|c|c|c|c|c|c|c|c|c|c|c|}
\hline \multirow[t]{3}{*}{ Faktor } & \multirow[t]{2}{*}{ Variabel } & \multicolumn{9}{|c|}{ Pendapat Responden } \\
\hline & & R1 & $\mathbf{R 2}$ & R3 & R4 & R5 & R6 & R7 & R8 & R9 \\
\hline & Karakteristik penduduk & $\mathrm{S}$ & $\mathrm{S}$ & $\mathrm{S}$ & TS & $\mathrm{S}$ & $\mathrm{S}$ & $\mathrm{S}$ & $\mathrm{S}$ & $\mathrm{S}$ \\
\hline \multirow[t]{3}{*}{ Faktor Sosial } & $\begin{array}{l}\text { Pengetahuan dan pemahaman } \\
\text { masyarakat tentang RTH }\end{array}$ & $\mathrm{S}$ & $\mathrm{S}$ & $\mathrm{S}$ & $\mathrm{S}$ & $\mathrm{S}$ & $\mathrm{S}$ & $\mathrm{S}$ & $\mathrm{S}$ & $\mathrm{S}$ \\
\hline & $\begin{array}{l}\text { Rasa kepedulian dan kesadaran } \\
\text { masyarakat dalam menjaga RTH }\end{array}$ & $\mathrm{S}$ & $\mathrm{S}$ & $\mathrm{S}$ & $\mathrm{S}$ & $\mathrm{S}$ & $\mathrm{S}$ & $\mathrm{S}$ & $\mathrm{S}$ & $\mathrm{S}$ \\
\hline & Tingkat partisipasi masyarakat & $\mathrm{S}$ & $\mathrm{S}$ & $\mathrm{S}$ & $\mathrm{S}$ & $\mathrm{S}$ & $\mathrm{S}$ & $\mathrm{S}$ & $\mathrm{S}$ & $\mathrm{S}$ \\
\hline
\end{tabular}

Keterangan :

S / TS : Setuju / Tidak Setuju

R1 : Sudin Pertamanan dan Pemakaman Jakarta Utara

R2 : Kepala Subbidang Prasarana Sarana Kota dan Lingkungan Hidup Bappeko Jakarta Utara

R3 : Kepala Bag. Prasarana Sarana Kota dan Lingkungan Hidup BPLHD Jakarta Utara

R4 : Staff Bina Penataan Bangunan Cipta Karya

R5 : Staff Property Development Summarecon Agung

R6 : Kepala Divisi Perencanaan PT. Jakarta Propertindo

R7 : Kepala Forum Peduli Lingkungan Masyarakat Kelapa Gading

R8 : Aktivis HiddenPark

R9 : Tokoh Masyarakat

Berdasarkan hasil Delphi tahap I, diketahui bahwa terdapat 4 aspek yang tidak mencapai konsensus responden, yaitu Jumlah lahan kosong yang difungsikan menjadi RTH, status kepemilikan lahan, jumlah penduduk dan karakteristik penduduk. Sehingga dilakukan delphi tahap II yang berisikan keempat aspek yang sebelumnya tidak mencapai konsensus. Hasil analisis Delphi tahap II adalah sebagai berikut :

Tabel 2

Hasil Analisis Delphi Tahap II

\begin{tabular}{l|l|c|c|c|c|c|c|c}
\hline \multirow{2}{*}{ Aspek } & \multicolumn{1}{|c|}{ Variabel } & \multicolumn{6}{|c}{ Pendapat Responden } \\
\cline { 3 - 8 } & & R1 & R2 & R3 & R4 & R5 & R6 & R7 \\
\hline $\begin{array}{l}\text { Faktor Tata } \\
\text { Guna } \\
\text { Lahan }\end{array}$ & $\begin{array}{l}\text { Jumlah lahan } \\
\text { kosong yang } \\
\text { difungsikan } \\
\text { menjadi RTH }\end{array}$ & S & S & S & S & S & S & S \\
& & & & & & & \\
\cline { 2 - 9 } & $\begin{array}{l}\text { Status } \\
\text { kepemilikan } \\
\text { lahan }\end{array}$ & TS & TS & TS & TS & TS & TS & TS \\
\hline $\begin{array}{l}\text { Faktor } \\
\text { Demografi }\end{array}$ & $\begin{array}{l}\text { Jumlah } \\
\text { Penduduk }\end{array}$ & S & S & S & S & S & S & S \\
\cline { 2 - 9 } & $\begin{array}{l}\text { Karakteristik } \\
\text { Penduduk }\end{array}$ & S & S & S & S & S & S & S \\
\hline
\end{tabular}

Berdasarkan hasil Delphi tahap II, diketahui bahwa terdapat 1 faktor yang tidak disetujui oleh seluruh responden yaitu status kepemilikan lahan. Hal itu dikarenakan beberapa hal, yaitu kurang relevannya permasalahan sengketa lahan dengan kondisi saat ini serta adanya pendapat responden yang menyatakan bahwa sengketa lahan dapat diselesaikan dengan melalui ketegasan dari pihak pemerintah.

\section{Arahan Optimalisasi RTH Publik di Kecamatan Kelapa} Gading

Setelah diketahui kebutuhan RTH berdasarkan preferensi masyarakat serta faktor-faktor yang berpengaruh dalam optimalisasi RTH publik di Kecamatan Kelapa Gading, hasil tersebut dijadikan input dalam proses perumusan arahan di sasaran 4 ini. Arahan optimalisasi RTH Publik Kecamatan Kelapa Gading meliputi :

1) Pengoptimalan RTH dengan fungsi kawasan resapan, paru-paru kota dan peneduh.

2) Penyediaan fasilitas sosial dan pengadaan kegiatan sosialbudaya rutin.

3) Penyediaan taman dengan fasilitas olahraga dan fasilitas permainan anak.

4) Mempertahankan komposisi tanaman hias dan memilih jenis tanaman yang aman bagi anak-anak.

5) Penanaman tanaman yang memiliki nilai jual

6) Adanya satuan tugas taman

7) Pengadaan CSR dalam pengelolaan RTH publik dan adanya kerjasama melalui program pengelolaan RTH bersama antara pihak pemerintah dan swasta. Serta pemberian insentif pada pihak swasta yang terlibat aktif dalam pengelolaan RTH.

8) Mewajibkan $\mathrm{KDH} 20 \%$ pada setiap fasilitas sosial dan fasilitas umum yang dibangun di Kecamatan Kelapa Gading

9) Menjadikan fasos - fasum sebagai RTH dan menerapkan konsep RTH secara vertikal.

10) Menetapkan kawasan RTH Publik, melakukan refungsi lahan SPBU yang diperuntukkan sebagai RTH, serta menetapkan status kepemilikan suatu lahan.

11) Pemerataan jumlah dan luasan RTH di 3 Kelurahan yang ada di Kecamatan Kelapa Gading

12) Sosialisasi terhadap masyarakat terkait pentingnya keberadaan RTH.

13) Mengajak masyarakat ikut serta dalam kegiatan pengelolaan RTH publik dan memberikan apresiasi terhadap masyarakat yang ikut serta dalam kegiatan pengelolaan RTH publik.

14) Pemberian insentif terhadap peran serta masyarakat serta menjadikan komunitas lingkungan sebagai pelopor gerakan peduli RTH

\section{KESIMPULAN}

Berdasarkan hasil dan pembahasan pada penelitian ini, maka dapat disimpulkan sebagai berikut :

1) Karakteristik RTH Publik Kecamatan Kelapa Gading 
a. Terdiri dari 3 jenis RTH publik di yaitu taman kota, taman lingkungan dan jalur hijau

b. Memiliki fungsi ekologis (peneduh), fungsi sosial (tempat rekreasi), serta fungsi estetis (pembentuk keindahan arsitektural)

c. Skala RTH meliputi skala kota dan skala RW

d. RTH publik yang ada merupakan RTH buatan

e. Luas RTH publik saat ini $\left(181.516,47 \mathrm{~m}^{2}\right)$ sudah memenuhi standar yang diharuskan $\left(31.332 \mathrm{~m}^{2}\right)$

f. Karakteristik vegetasi didominasi oleh tanaman peneduh dan tanaman hias

2) Kebutuhan RTH berdasarkan preferensi Masyarakat

a. Fungsi ekologis sebagai kawasan resapan, paru-paru kota, serta peneduh.

b. Fungsi sosial sebagai tempat rekreasi, media komunikasi warga kota, serta menggambarkan ekspresi budaya lokal.

c. Fungsi estetis untuk meningkatkan kenyamanan dan memperindah lingkungan, pembentuk arsitektural serta menstimulasi kreativitas dan produktivitas masyarakat.

d. Fungsi ekonomi sebagai sumber produk yang bisa dijual

3) Faktor Pengaruh Optimalisasi RTH Publik Kecamatan Kelapa Gading

a. Faktor Kelembagaan : penyelenggaraan program terkait $\mathrm{RTH}$, pengawasan dan pengelolaan pemerintah, serta koordinasi dan kerjasama pihak swasta.

b. Faktor Tata Guna Lahan : adanya lahan kosong yang berfungsi sebagai RTH dan pemanfaatan lahan.

c. Faktor Demografi : jumlah penduduk, tingkat pertumbuhan penduduk, serta karakteristik penduduk.

d. Faktor Sosial : wawasan masyarakat, kepedulian masyarakat, tingkat partisipasi masyarakat

4) Arahan Optimalisasi RTH Publik Kecamatan Kelapa Gading

a. Pengoptimalan RTH dengan fungsi kawasan resapan, paru-paru kota dan peneduh.

b. Penyediaan fasilitas sosial dan pengadaan kegiatan sosial-budaya rutin.

c. Penyediaan taman dengan fasilitas olahraga dan fasilitas permainan anak.

d. Mempertahankan komposisi tanaman hias dan memilih jenis tanaman yang aman bagi anak-anak.

e. Penanaman tanaman yang memiliki nilai jual

f. Adanya satuan tugas taman

g. Pengadaan CSR dalam pengelolaan RTH publik dan adanya kerjasama melalui program pengelolaan RTH bersama antara pihak pemerintah dan swasta. Serta pemberian insentif pada pihak swasta yang terlibat aktif dalam pengelolaan RTH.

h. Mewajibkan KDH $20 \%$ pada setiap fasilitas sosial dan fasilitas umum yang dibangun di Kecamatan Kelapa Gading

i. Menjadikan fasos - fasum sebagai RTH dan menerapkan konsep RTH secara vertikal. j. Menetapkan kawasan RTH Publik, melakukan refungsi lahan SPBU yang diperuntukkan sebagai RTH, serta menetapkan status kepemilikan suatu lahan.

k. Pemerataan jumlah dan luasan RTH di 3 Kelurahan yang ada di Kecamatan Kelapa Gading

1. Sosialisasi terhadap masyarakat terkait pentingnya keberadaan RTH.

m. Mengajak masyarakat ikut serta dalam kegiatan pengelolaan RTH publik dan memberikan apresiasi terhadap masyarakat yang ikut serta dalam kegiatan pengelolaan RTH publik.

n. Pemberian insentif terhadap peran serta masyarakat serta menjadikan komunitas lingkungan sebagai pelopor gerakan peduli RTH

o. Menyelenggarakan program "Satu Anak Satu Pohon"

\section{DAFTAR PUSTAKA}

[1] Undang-Undang Republik Indonesia Nomor 26. Tahun 2007 tentang Penataan Ruang. (2007). Jakarta: Badan Koordinasi Tata Ruang Nasional. (Prof. Dr. Sumarmi, 2010)

[2] PU, M. (2008). Pedoman Penyediaan dan Pemanfaatan RTH di Perkotaan.

[3] Umum, K. P. (2011). Program Pengembangan Kota Hijau. Jakarta: Kementerian Pekerjaan Umum.

[4] Dinas Pertamanan dan Pemakaman DKI Jakarta. (2013)

[5] Joga, N., \& Ismaun, I. (2011). RTH 30\%! Resolusi (Kota) Hijau. Gramedia Pustaka Utama.

[6] Dinas Pertamanan dan Pemakaman DKI Jakarta. (2013)

[7] Kecamatan Kelapa Gading Dalam Angka (2015)

[8] Dinas Pertamanan dan Pemakaman DKI Jakarta. (2013)

[9] PU, M. (2008). Pedoman Penyediaan dan Pemanfaatan RTH di Perkotaan.

[10] Badan Nasional Penanggulangan Bencana. (2014)

[11] Profil Kecamatan Kelapa Gading. (2015)

[12] Mubarak, H. (2012, 02 29). Merawat Jakarta dengan Hadirnya Ruang Terbuka Hijau dan Ruang Publik yang Sehat.

[13] Rakyat, S. K. (2015, 05 12). Kelapa Gading Barat Kembangkan Tanaman.

[14] Megapolitan (2015). Kondisi Taman Interaksi Kelapa Gading Memprihatinkan. 